\title{
Effects of Cooperative E-Learning Approach on Students' Chemistry Achievement in Koibatek Sub-County, Kenya
}

\author{
Roselyn Chebii, S. W. Wachanga, Z. O. Anditi \\ Department of Curriculum Instruction and Educational Management, Egerton University, Njoro, Nakuru, Kenya \\ Email: roselynchb@gmail.com
}

How to cite this paper: Chebii, R., Wachanga, S. W., \& Anditi, Z. O. (2018). Effects of Cooperative E-Learning Approach on Students' Chemistry Achievement in Koibatek Sub-County, Kenya. Creative Education, 9, 1872-1880.

https://doi.org/10.4236/ce.2018.912137

Received: July 9, 2018

Accepted: September 26, 2018

Published: September 29, 2018

Copyright (c) 2018 by authors and Scientific Research Publishing Inc. This work is licensed under the Creative Commons Attribution International License (CC BY 4.0).

http://creativecommons.org/licenses/by/4.0/

\begin{abstract}
The study investigated the effectiveness of Co-operative E-learning approach (CELA) on secondary school students' achievement in Chemistry. It was carried out in Koibatek sub county in Kenya, where there has been persistent low achievement in the subject. The Solomon Four Group, Non-equivalent Control Group Design was employed in the study. Three students from twelve county schools, purposively selected from 40 secondary schools were taught the same course content on the topic "mole" for a period of five weeks. The experimental groups $\left(\mathrm{E}_{1}\right.$ and $\left.\mathrm{E}_{2}\right)$ received their instruction through the use of CELA approach and control groups $\left(C_{1}\right.$ and $\left.C_{2}\right)$ using the conventional teaching method. The researcher trained the teachers in the experimental groups on the technique of CELA before treatment. The Chemistry Achievement Test (CAT) was used for data collection. Pre-test was administered to students in the experimental group $\left(\mathrm{E}_{1}\right)$ and control group $\left(\mathrm{C}_{1}\right)$ before teaching commences and after the teaching a post-test was administered to the four groups. The instrument was pilot tested to ascertain its reliability. The data collected was analyzed using t-test, ANOVA and ANCOVA. Hypothesis of the study was tested at $\alpha=0.05$ level of significance. Results indicated that, the students in the experimental groups outperformed the control groups in the Chemistry Achievement Test. It was concluded that CELA enhanced better performance in Chemistry than conventional teaching method. Science teachers, educationist and policy makers are expected to benefit from the findings of the study. It should be included in regular pre-services and in-service training of Chemistry teachers in Kenya.
\end{abstract}

\section{Keywords}

Cooperative E-Learning Approach (CELA), Achievement in Chemistry, Conventional Teaching Method 


\section{Introduction}

The role of science education in the lives of individuals and in the advancement of science and technology for the development of mankind and society in general is very crucial. Oludipe and Awokoya (2010) argued that scientific literacy is the gateway to achieve scientific and technological advancement through science education. The integration of technology in teaching is still challenging for most teachers even though there has been availability of technology tools in schools. Teachers have not incorporated technology in their teaching for various reasons, such as lack of knowledge of technology, time and support. Chemistry enables the learners to understand what happens around them. Since Chemistry topics are generally related to or based on the structure of matter; it proves to be a difficult subject for many students. Chemistry curriculum incorporates many abstract concepts which are central to further learning in both Chemistry and other sciences (Taber, 2002). Voska and Heikkinen (2002) suggest that understanding of mole concept is fundamental to students' understanding of other chemical topics such as molecular mass, molar concentration, molar volume $\mathrm{pH}$ and chemical equilibrium. "Mole" is one of the concepts in Chemistry that is abstract, and hence students have difficulties in understanding and applying their knowledge during problem solving. Cooperative learning is an approach of organizing classroom activities into academic and social learning experience. Students work in groups to complete a task collectively. Students cooperatively rely on one another for information evaluating one another's ideas, monitoring one another's work (Chiu, 2008). E-learning is the use of electronic media and Information and Communication Technologies (ICT) in education. CELA is an acronym got by integrating existing cooperative learning and E-learning. It was an approach used in teaching the experimental groups in the study to see whether it improved in the Chemistry achievement.

\subsection{Purpose of the Study}

The purpose of the study was to determine the Effects of Cooperative E-learning Approach (CELA) on Students Achievement in Chemistry.

\subsection{Objective of the Study}

The specific objective of the study was to compare the achievement of students who were taught Chemistry using Cooperative E-learning (CELA) and those not exposed to CELA.

\subsection{Hypothesis of the Study}

The following null hypothesis was tested in this study at significance level of 0.05 .

Ho1: There is no statistically significant difference between the Chemistry achievement of students who are exposed to CELA and those who are not exposed to it. 


\subsection{Research Design}

The study used Solomon Four Non-equivalent Control Group Design. This is because there was non-random selection of students to the groups. Secondary school classes exist as intact groups and school authorities do not normally allow the classes to be dismantled and constitute for research purposes (Fraenkel \& Wallen, 2009).

Four groups of participants, the Experimental Group One $\left(\mathrm{E}_{1}\right)$. Experimental Group Two $\left(\mathrm{E}_{2}\right)$, Control Group One $\left(\mathrm{C}_{1}\right)$ and Control Group Two $\left(\mathrm{C}_{2}\right)$ was used. Groups $\mathrm{E}_{1}$ and $\mathrm{E}_{2}$ formed the experimental groups which received treatment (CELA) while $\mathrm{C}_{1}$ and $\mathrm{C}_{2}$ were the Control Group that did not receive treatment. Groups $\mathrm{E}_{1}$ and $\mathrm{C}_{1}$ received pre-test while $\mathrm{E}_{2}$ and $\mathrm{C}_{2}$ did not. All groups received the post-test at the end of the course. To avoid interaction of students from different groups that may contaminate the results of the study; one class from a school constituted one group of students. The selected classes were randomly assigned to the experimental and control groups (Burg \& Gall, 1996; Mugenda \& Mugenda, 2003) (Table 1).

\subsection{Sample}

The actual sample size that participated was 489 form three students selected using purposive sampling method from 12 county schools which met the requirements (having computers, laboratories, apparatus, qualified Chemistry teachers and could easily be accessed using the Nakuru-Eldama Ravine road) situated in Koibatek sub-county, Kenya (Table 2).

\subsection{Instrumentation}

Chemistry Achievement Test (CAT) was used to collect the data. The Chemistry Achievement Test was used to assess the learner's mastery of content on the topic "The Mole" in secondary Chemistry. Nineteen items of short answer and structured questions on mole based on KCID Chemistry syllabus was used in scoring of individual items (KIE, 2002). The instrument was pilot tested in two secondary schools with similar characteristics in Koibatek sub-county but did not take part in the study. The reliability was estimated using Cronbach's alpha and a reliability coefficient of 0.87 . Reliability coefficient level is above 7 hence acceptable. This implied that there was a good internal consistency of items (Frankel \& Wallen, 2009).

\subsection{Data Collection Procedure}

The students in the study were randomly assigned into the four groups experimental group $1\left(\mathrm{E}_{1}\right)$, experimental group $2\left(\mathrm{E}_{2}\right)$, control group $1\left(\mathrm{C}_{1}\right)$ and Control group $2\left(\mathrm{C}_{2}\right)$. A pre-test was conducted in experimental group $\left(\mathrm{E}_{1}\right)$ and one control group $\left(\mathrm{C}_{1}\right)$ in order to measure the student entry behavior before the treatment. In experimental group $\mathrm{E}_{1}$ and $\mathrm{E}_{2}$ CELA was used while in control groups $\mathrm{C}_{1}$ and $\mathrm{C}_{2}$ conventional teaching method was used. 
At the end of the treatment period the post test (CAT) was administered to all the groups. The researcher supervised the teaching and scored the pre-test and post-test.

\subsection{Data Analysis}

To test for differences between two means, t-test was used. However, for more than two means ANOVA and ANCOVA were used. The hypothesis was tested at $\alpha=0.05$ level of significance.

\section{Results}

The pre-test was administered to groups $\mathrm{E}_{1}$ and $\mathrm{C}_{1}$ to determine the student's entry behavior before teaching started. Table 3 shows the pre-test results.

Mean difference not significant at 0.05 . The results in Table 3 revealed that the difference in students scores in the CAT were not statistically significant; $t$ $(262)=1.50 p>0.05$. This indicates that the groups used in the study exhibited comparable characteristics and therefore suitable for the study.

\section{Effects of CELA on Student Achievement Scores on Chemistry in Secondary Schools}

To determine the relative effect of CELA on students achievement in Chemistry, an analysis of the students post-test CAT scores was carried out. The hypothesis of the study sought to find out whether there was any statistically significant difference between achievement of students who were exposed to CELA and those who were not. Table 4 shows the mean scores of the four groups.

Results shown in Table 4 indicate that experimental groups $\mathrm{E}_{1}$ and $\mathrm{E}_{2}$ achieve higher mean scores than the control groups $C_{1}$ and $C_{2}$. This shows that CELA had an effect of improving performance as compared to the conventional teaching method. ANOVA was also carried out to establish whether the differences in mean scores were significant. The results are shown in Table 5.

Results in Table 5 indicate that a statistically significant difference exists between the post-test mean scores of the groups $\mathrm{f}(3483)=113.09 p<0.05$. The null hypothesis could be rejected but the findings could not indicate where the difference was. It was necessary to carryout Least Significance Difference (LSD) post hoc comparison, to know which groups were statistically significant different. Table 6 shows the post hoc comparison of the CAT mean scores for the group $\mathrm{E}_{1}, \mathrm{C}_{1}, \mathrm{E}_{2}$ and $\mathrm{C}_{2}$.

Table 6 shows that CAT means of groups $\mathrm{E}_{2}$ and $\mathrm{C}_{1}$, groups $\mathrm{E}_{1}$ and $\mathrm{C}_{2}$, groups $\mathrm{E}_{1}$ are significantly different at $0.05 \alpha$ level. However, there was no significant difference. In the means between groups $\mathrm{E}_{1}$ and $\mathrm{E}_{2}$ and $\mathrm{C}_{1}$ and $\mathrm{C}_{2}$.

From these results the subjects in the experimental conditions out-performed the subjects that were in control groups. The researchers concluded that the CELA approach used by the experimental groups led to a relatively higher achievement in the learning of the Chemistry of Mole than the conventional methods used in the control groups. 
Since the study involved non-equivalent control group design, there was need to confirm those results by performing analysis of covariance (ANCOVA) using students Kenya Certificate of Primary Education (KCPE) scores as covariate. Analysis of covariate reduces the effects of initial group differences statistically by making compensating adjustments to the post-test means of the groups involved (Borg \& Gall, 1996; Wachanga, 2002). Table 7 shows adjusted CAT post-test mean scores with KCPE as the covariant.

Table 8 shows the ANCOVA results based on the adjusted means of the four groups displayed in Table 7.

The results confirm the difference between the means are significant at 0.05 level $\mathrm{f}(3478)=127.09, p<0.05$. The pairwise comparison was carried out as shown in Table 9.

Table 1. Solomon four Non-equivalent control group design.

\begin{tabular}{cccc}
\hline Group & Pre-test & Treatment & Post-test \\
\hline $\mathrm{E}_{1}$ & $\mathrm{O}_{1}$ & $\mathrm{X}$ & $\mathrm{O}_{2}$ Experimental \\
$\mathrm{C}_{1}$ & $\mathrm{O}_{2}$ & - & $\mathrm{O}_{4}$ Control \\
$\mathrm{E}_{2}$ & - & $\mathrm{X}$ & $\mathrm{O}_{5}$ Experimental \\
$\mathrm{C}_{2}$ & - & - & $\mathrm{O}_{6}$ Control \\
\hline
\end{tabular}

Source: Fraenkel \& Wallen, 2009. (O): Indicates observation or outcomes. (X): Indicates treatment. (------) Indicate the use of non-equivalent groups.

Table 2. Sample Size.

\begin{tabular}{cc}
\hline Group & Number of students \\
\hline E1 & 141 \\
E2 & 123 \\
C1 & 120 \\
C2 & 105 \\
Total & $\mathbf{4 8 9}$ \\
\hline
\end{tabular}

Table 3. The Independent Samples t-test of the pre-test Mean Score on CAT.

\begin{tabular}{cccccccc}
\hline TEST & GROUP & N & MEAN & SD & df & t-value & $P$-Value \\
\hline CAT & E1 & 141 & 10.28 & 7.34 & 262 & 1.50 & 0.14 \\
& C1 & 122 & 11.61 & 6.92 & & & \\
\hline
\end{tabular}

Table 4. CAT Post-test mean scores obtained by the students in four groups.

\begin{tabular}{cccc}
\hline GROUP & $\mathbf{N}$ & MEAN & STANDARD DEVIATION \\
\hline E1 & 139 & 44.88 & 15.30 \\
C1 & 120 & 23.48 & 11.17 \\
E2 & 123 & 48.45 & 15.22 \\
C2 & 105 & 24.64 & 11.35 \\
\hline
\end{tabular}


Table 5. ANOVA of the post-test mean score on the CAT.

\begin{tabular}{ccccccc}
\hline TEST & GROUP & SS & Df & Mean Square & F & P-Value \\
\hline CAT & Between groups & $62,381.72$ & 3 & $2,079,391$ & 113.09 & $0.00^{*}$ \\
& Within groups & $88,811.5$ & 483 & 183.88 & & \\
\multirow{2}{*}{ Total } & & $151,193.2$ & 486 & & & \\
\hline
\end{tabular}

Mean difference is significant at 0.05 levels.

Table 6. Post hoc comparison of the CAT, Post-test mean scores for four groups.

\begin{tabular}{ccc}
\hline Paired Group & Mean Difference & $\boldsymbol{P}$-Value \\
\hline $\mathrm{E}_{1}-\mathrm{C}_{1}$ & 21.40 & $0.00^{*}$ \\
$\mathrm{E}_{1}-\mathrm{E}_{2}$ & -3.57 & 0.21 \\
$\mathrm{E}_{1}-\mathrm{C}_{2}$ & 20.24 & $0.00^{*}$ \\
$\mathrm{C}_{1}-\mathrm{E}_{2}$ & -24.97 & $0.00^{*}$ \\
$\mathrm{C}_{1}-\mathrm{C}_{2}$ & -1.16 & 0.94 \\
$\mathrm{E}_{2}-\mathrm{C}_{2}$ & 23.81 & $0.00^{*}$ \\
\hline
\end{tabular}

* Significant at 0.05 level.

Table 7. Adjusted CAT post-test Mean Scores with KCPE as the Covariant.

\begin{tabular}{cccc}
\hline GROUP & $\mathrm{N}$ & MEAN & STANDARD DEVIATION \\
\hline $\mathrm{E}_{1}$ & 139 & 46.42 & 1.17 \\
$\mathrm{C}_{1}$ & 120 & 22.35 & 1.23 \\
$\mathrm{E}_{2}$ & 123 & 48.52 & 1.21 \\
$\mathrm{C}_{2}$ & 105 & 24.40 & 1.29 \\
\hline
\end{tabular}

Table 8. Analysis of Covariance (ANCOVA) of the Post-test Scores of CAT with KCPE as Covariant.

\begin{tabular}{cccccc}
\hline Source & Sum of squares & Df & Mean squares & F-ratio & $p$-value \\
\hline KCPE Score & 3703.10 & 1 & 3703.10 & 21.09 & 0.00 \\
Group & $66,936.90$ & 3 & $22,312.30$ & 127.09 & $0.00^{*}$ \\
Error & $83,919.99$ & 478 & 175.57 & & \\
Total & $782,932.00$ & 483 & & & \\
\hline
\end{tabular}

* Significant at 0.05 level.

Table 9. Pairwise Comparison's Post-test mean scores of CAT.

\begin{tabular}{ccc}
\hline PAIRED GROUP & MEAN DIFFERENCE & $\boldsymbol{P}$-VALUE \\
\hline $\mathrm{E}_{1}-\mathrm{C}_{1}$ & 24.07 & $0.00^{*}$ \\
$\mathrm{E}_{1}-\mathrm{E}_{2}$ & -2.10 & 0.22 \\
$\mathrm{E}_{1}-\mathrm{C}_{2}$ & 22.02 & $0.00^{\star}$ \\
$\mathrm{C}_{1}-\mathrm{E}_{2}$ & -26.18 & $0.00^{\star}$ \\
$\mathrm{C}_{1}-\mathrm{C}_{2}$ & -2.06 & 0.25 \\
$\mathrm{E}_{2}-\mathrm{C}_{2}$ & 24.12 & $0.00^{*}$ \\
\hline
\end{tabular}

\footnotetext{
* Significant at 0.05 level.
} 
The post hoc pair wise comparisons based on the ANVOCA Table 8, shows that there is a statistically significant difference in the following groups.

1) Groups $E_{1}$ and $C_{1}$

2) Groups $E_{2}$ and $C_{1}$

3) Groups $E_{1}$ and $C_{1}$

4) Groups $E_{2}$ and $C_{2}$

Difference between $E_{1}$ and $E_{2}$ and groups $C_{1}$ and $C_{2}$ were not significant. It is evident the CELA had similar effects to both experimental groups. But the control groups $\mathrm{C}_{1}$ and $\mathrm{C}_{2}$ denied of this treatment had a lower mean scores and hence were out performed by the experimental groups. The results of ANOVA and ANCOVA confirm that there was a statistically significant difference in the mean scores of the experimental and control groups. Therefore HO1 was rejected.

\section{Discussions}

The researcher found that students who were taught through CELA achieved significantly higher scores in CAT compared to those taught through conventional method. These observations are in agreement with the finding of similar studies carried out earlier. Gambari (2010); Yusuf and Afolabi (2010), reported that the students exposed to computer assisted cooperative learning settings performed better than those exposed to the same programme individually. In cooperative settings the learners were divided into groups consisting of (5 - 6) students. Aluko (2004) argued that an adopted version of cooperative learning strategy required students to solve Chemistry problems together in small groups (usually 5 - 6 members per group), and the teacher acting as a facilitator. The topics taught to the two groups were gas laws and the mole. The results showed that these was a significant main effect of treatment for those using Cooperative instruction. In this study the topic taught was the "mole" and the results in Table 8 shows that there was statistically significant difference in the mean score.

Other research findings indicated that computer supported cooperative learning approved students learning and increased their academic achievement, problem solving skills, student-student interaction (Johnson \& Johnson, 2008). In this study CELA method enhanced their achievement and also there was student-student interaction. Khan and Inamullah, (2011) investigated the effect of a Students' Team Achievement Divisions (STAD) on academic achievement. Students studying Chemistry at higher secondary level in Khyber (Pakistan) participated. The post-test mean score indicated that the experimental group taught using STAD performed better in the test than the control group taught using conventional method. In this study Table 4 shows the mean scores of the experimental and control groups. $\mathrm{E}_{1}$ had $44.88, \mathrm{E}_{2}=48.45, \mathrm{C}_{1}=23.48$ and $\mathrm{C}_{2}=24.64$. The experimental groups performed better. Orora et al. (2014) conducted a similar study on the effect of cooperative e-learning on Biology in Nakuru county, Kenya. The method enhanced achievement and creativity in Biology among 
learners. These observations are in agreement with the studies done earlier. Else-Quest et al. (2010) reported that the teaching of Chemistry concepts through cooperative learning method was more effective in increasing academic achievement compared to the conventional teaching method.

\section{Conclusion}

In this article, an attempt was made to use the results of the study to test whether the hypothesis was false or true. From the post-test and pre-test results, the mean scores, obtained by students in groups $\mathrm{E}_{1}$ and group $\mathrm{C}_{1}$ were not statistically significant. But after treatment, the students who were exposed to CELA $\left(\mathrm{E}_{1}\right)$ outscored control $\left(\mathrm{C}_{1}\right)$. From the ANOVA results of the post-test there was the statistically significant difference in the means between the four groups. Adjusted means of the four groups showed that there was a statistically significant difference in the means of the four groups. From these results the hypothesis was rejected.

Based on this study, the researchers concluded that CELA facilitates students learning in Chemistry better than conventional teaching method. Therefore, the approach should be used in Chemistry teaching at secondary school level. Achievement is likely to improve and performance at KCSE examinations would be better. Chemistry teachers are encouraged to incorporate this method at their teaching.

\section{Conflicts of Interest}

The authors declare no conflicts of interest regarding the publication of this paper.

\section{References}

Aluko, K. O. (2004). Effects of Cooperative and Individualistic Instructional Strategies on Students Problem Solving Abilities Secondary School Chemistry in Llessa Nigeria. Unpublished PhD. Thesis, University of Ilorin Nigeria.

Borg, W. R., \& Gall, J. P. (1996). Educational Research (6 ${ }^{\text {th }}$ ed.). New York and London: Longman.

Chiu, M. M. (2008). Flowing toward Correct Contributions during Group Problem Solving. A Statistical Discourse Analysis. Journal of the Learning Sciences, 17, 415-463. https://doi.org/10.1080/10508400802224830

Else-Quest, N. M., Hyde, J. S., \& Linn, M. C. (2010). Cross National Patterns of Gender Differences in Mathematics and Gender Equity. A Meta Analysis. Psychological Bulletin, 136, 103-127. https://doi.org/10.1037/a0018053

Fraenkel, R. J., \& Wallen, E. N. (2009). How to Design and Evaluate Research in Education ( $7^{\text {th }}$ ed.). San Francisco: McGraw-Hills.

Gambari, I. A. (2010). Effects of Computer-Supported Cooperative Learning Strategies on the Performance of Senior Secondary Students in Physic as in Minna, Nigeria. Unpublished PhD. Thesis, University of Ilorin, Nigeria.

Johnson, D. W., \& Johnson, R. T. (2008). Cooperation and the Use of Technology. Handbook of Research on Educational Communication and Technology ( $3^{\text {rd }}$ ed.). New York: Lawrence, Eribaum Associations. 
Khan, N. G. in a Mullah, M. H. (2011). Effect of Students' Team Achievement Division (STAD) on Academic Achievement of Students. Asian Social Science, 7, 211-215. https://doi.org/10.5539/ass.v7n12p211

Mugenda, O., \& Mugenda, A. (2003). Research Methods Quantitative and Qualitative Approaches. Nairobi: Act Press.

Oludipe, D., \& Awokoya, J. O. (2010). Effect of Cooperative Teaching Strategy on the Reduction of Students' Anxiety for Learning Chemistry. Journal of Turkish Science Education, 7, 30-36.

Orora, W., Keraro, F. N., \& Wachanga, S. W. (2014). Using Cooperative E-Learning Teaching Strategy to Enhance Students' Creativity in Secondary School Biology. A Study of Selected Schools in Nakuru County, Kenya. International Journal of Education and Practice, 2, 137-146. https://doi.org/10.18488/journal.61/2014.2.6/61.6.137.146

Taber, K. S. (2002). Alternative Conceptions in Chemistry: Prevention Diagnosis and Cure? London: The Royal Society of Chemistry.

Voska, K. W., \& Heikkinen, H. W. (2002). Identification and Analysis of Student Conception Used to Solve Chemical Equilibrium Problems. Journal of Research in Science Teaching, 37, 160-176.

https://doi.org/10.1002/(SICI)1098-2736(200002)37:2<160::AID-TEA5>3.0.CO;2-M

Wachanga, S. W. (2002). Effects of Cooperative Class Experiment Teaching Method on Secondary School Students' Motivation and Achievement in Chemistry. Unpublished Ph.D Thesis, Egerton University, Njoro.

Yusuf, M. O., \& Afolabi, A. O. (2010). Effects of Computer Assisted Instruction on Secondary School Students, Performance in Biology. The Turkish Online. Journal of Educational Technology, 9, 62-69. http://www.to.jeteduc.com 